\section{India plans to demand compensation for effect of brain drain}

[NEW DELHI] India's delegation to the World Conference on Science plans to argue for compensation for the loss of trained manpower from developing to developed countries, according to Valangiman Ramamurthi, secretary of the Department of Science and Technology.

He says the delegation will also stress the need to protect unwritten traditional knowledge systems. It will seek funding from Unesco for critical areas of science of economic importance, as well as for regional networking of existing facilities.

The conference will be attended by an eight-member official delegation from Indian ministries of education and science, led by science minister Murli Manohar Joshi. "We expect that the non-official delegation from science academies, universities and private organizations - will be much bigger," says Ramamurthi.

Despite the government's unhappiness with the NATO bombing of Serbia and the handling of the Kosovo crisis by the United States, officials in New Delhi say that this is unlikely to influence their participation in the conference. "We in the science ministry have been preparing seriously for this event and planning to play an active role," says Ramamurthi, adding that the Indian strategy for the meeting will be finalized next week.

He says India is pleased that some of the suggestions made at a preparatory meeting in Bangalore have been included in the latest revision of the proposed Framework for Action to be adopted at the conference.

Full text: http://helix.nature.com/wcs/a34.html

\title{
University women seek a central role at Budapest
}

[LONDON] A major international organization concerned with the position of women in universities has criticized the draft of a declaration due to be adopted at the World Conference on Science, arguing that it makes too little reference to issues relating to women in science.

The International Federation of University Women (IFUW), a non-profit organization of more than 180,000 women graduates, says women's issues are in danger of being marginalized at the conference by being allocated to a special afternoon workshop.

But Unesco officials reply that the Framework for Action document to be adopted at the meeting gives a detailed treatment of the issue. Anna-Maria Cetto says a dedicated session was chosen because the issue warranted "special attention" and argues that "you need to be proactive to change a situation". She adds: "It hasn't meant marginalizing women, you can be sure of that."

Muriell Joye, IFUW secretary general, says: "Our experience is that it is very dangerous to have a special event for women." The IFUW, which brings together 66 national federations and associations, was closely involved in Unesco's World Conference of Higher Education last summer.

"At the World Conference of Higher Education, only women attended [a similar] session, and the point was lost," says Joye. "When issues [affecting women], such as age and research grants, were raised in conference, we received comments such as 'you have your panel for that'. We were pushed aside."
Joye says women are barely mentioned in the draft declaration and in a document submitted to Unesco and the International Council of Science (ICSU) as part of the preparatory discussion for the Budapest meeting. IFUW says that "too often women are linked to, or even described as, minorities", although they make up more than half the population. Joye adds that the organization does not have the resources to provide a detailed response to the lengthy framework document.

"Marginalizing women at the conference by mention in a single paragraph, and a special afternoon workshop on science and gender, will only help perpetuate the misunderstanding that the lack of women in science is a curiosity but of little general importance," says the IFUW statement. "It must be seen as a failure to develop the potential of half the possible scientific resource base."

Cetto says having a special session has allowed preparatory meetings on the topic of women in science in the run-up to the conference, which have made "productive progress". "There is now much more clarity of what the issues are. I think the [women in science] session will be better for the preparatory work. It has enabled comparisons between Africa, Europe and Latin America."

"All the comments received until two days ago are being taken note of," says Cetto. She says she has not seen the list of responses yet but says that organizations such as the Third World Organization for Women in Science have been "close to the process". Full text: http://helix.nature.com/wcs/a32a.htm

\section{Access to scientific knowledge 'should be a basic human right'}

[MONTEVIDEO] Scientific and technological literacy is a "social and ethical right of all human beings", according to Eduardo Martinez, a regional specialist in science and technology management at the Unesco office in Montevideo, Uruguay.

$\mathrm{He}$ argues that one of the major challenges facing developing countries is therefore to make science and technology an essential part of the culture. "The popularization of science and technology must make such knowledge a central component of culture, of social awareness and of collective intelligence."

Martinez points out that the technical possibilities of gaining access to

information are changing our vision of the world. "Today, access to knowledge is synonymous with development, well-being and quality of life."

He argues that the areas to be reached by science and technology must be broadened to integrate formal education and communication with informal efforts in both fields, academic discourse with colloquial language, and laboratory materials with domestic objects and ordinary daily achievements.

Activities leading to the popularization of science and technology must be based on interdisciplinary dialogue and work, integrating diverse fields of knowledge and different theoretical and methodological approaches, he says.

Martinez points out that in the past few years many interdisciplinary teams have been formed in Latin America to tackle the problem of communicating science and technology to large audiences. Many isolated experiments are now coordinated through the Network for the Popularization of Science and Technology in Latin America and the Caribbean (Red-POP).

Red-POP embraces more than 70 science and technology popularization centres and programmes. Its next biennial meeting will be held in June in Rio de Janeiro. Full text: http://helix.nature.com/wcs/c16.html 